\title{
THE SYSTEM OF FOOD LAW IN THE EUROPEAN UNION
}

\author{
Bernd M J VAN DER MeULen*
}

\begin{abstract}
The first decade of the twenty-first century has seen a complete recast of the regulatory infrastructure for food in the European Union (EU), changing its previously strict market orientation and turning it into an instrument with the primary objective of ensuring food safety. This article contributes to the comparative study of food law by analysing the new body of EU food law and bringing the underlying structure to the forefront. EU food law applies an holistic approach to the food chain, addressing, on the basis of scientific risk analysis: food as a product in terms of its accepted ingredients and the limits placed on contaminants; the processes of food production, trade and risk management; and the presentation of food in advertising and labelling. The European Commission and the Member States share responsibility for official controls, incident management and enforcement.
\end{abstract}

\section{INTRODUCTION}

\section{A In Search of Structure}

We started to develop food law as a 'functional' area of law - as an academic discipline in its own right - after I came to the chair of Law and Governance at Wageningen University (Netherlands) in September 2001. One of the first questions we confronted as a basis for both research and teaching was the question 'what is the structure and what is the system of food law?' At first sight food law in the European Union (EU) presents itself as an endless number of provisions of a very technical and detailed nature. ${ }^{1}$ Some authors

\footnotetext{
* Professor of Law and Governance at Wageningen University, the Netherlands $<$ www.law.wur.nl/UK/ >; chairman of the Dutch Food Law Association < www.NVLR.nl >; director of the European Institute for Food Law <www.food-law.nl >. Comments are welcome at: Bernd.vanderMeulen@wur.nl.

1 'Between 1 January 1997 and 10 November 2006, the Official Journal published 1359 measures addressing the food industry in whole or in part': J H M Wijnands, B M J van der Meulen and K J Poppe(eds), Competitiveness of the European Food Industry: An Economic
} 
dealing with the subject matter resorted to treating subjects in alphabetical order. Our conviction that it would be possible to organise the subject matter was not met with disappointment. We presented our view on food law in books that we prepared in the first place as teaching materials: Food Safety Law in the European Union (2004) ${ }^{2}$ and European Food Law Handbook (2008). ${ }^{3}$ Our current understanding of the structure of EU food law is presented in graphic form in the next section of this article and is further elaborated in the remainder of the article.

At the inaugural conference in January 2009 at Deakin University (Geelong, Australia), it was proposed to start an International Association of Food Law and Policy. It was further proposed to start a cooperative project on comparative food law. In this context I suggested that we should see whether it would be possible to adapt the framework we have developed for studying European food law such that it would be applicable to other jurisdictions as well, and thus make it possible to compare food law worldwide. The lukewarm reception this suggestion received was no small disappointment for me. Some considered it to be too ambitious, others to be boring. Instead, it was decided to present highlights of the developments in the different countries. Thus, the majority of project participants seem to value inductive research methods focusing on details over deductive approaches focusing on structure.

Maybe this outcome of the discussion can be seen as a first comparative law result. In an American booklet on comparative law, I found the following remark:

$[\mathrm{O}]$ ne of the greatest differences between legal education in common law and civil law systems appears in the manner in which the student is initiated into the study of law. While an American law student typically spends the first days of law school reading cases and having his or her attention directed over and over again to their precise facts, a student of the civil law is provided at the outset with a systematic overview of the framework of the entire legal system. The introductory text (a treatise, not a casebook) may even include a diagram depicting 'The Law' as a tree, ${ }^{4}$ with its two great divisions, public and private, branching off into all their many subdivisions

and Legal Assessment (2006) Office for Official Publications of the European Communities $64<$ http://ec.europa.eu/enterprise/food/competitiveness study.pdf $>$ at 16 August 2009.

${ }^{2}$ Bernd van der Meulen and Menno van der Velde, Food Safety Law in the European Union: An Introduction (2004).

${ }^{3}$ Bernd van der Meulen and Menno van der Velde, European Food Law Handbook (2008). See $<$ http://www.wageningenacademic.com/foodlaw $>$.

${ }^{4}$ Such a diagram can indeed be found in Van der Meulen and Van der Velde, Handbook, above n 3, 50-1 (footnote added by the present author). 
and categories - each of which will become, in turn, the subject of later study...

Systematisation is not limited to education in the civil law systems:

[A]ll other actors in the legal system receive their training from the scholars who transmit to them a comprehensive and highly-ordered model of the system that to a great extent controls how they organize their knowledge, pose their questions and communicate with each other. This model is not only taught in the universities but constitutes the latent framework of the treatises and articles produced by the professors. Furthermore, legal periodicals, which in civil law countries are run by professors rather than students, play a much more important role there than in common law countries in bringing new legislation and court opinions to the attention of the profession. ${ }^{6}$

So maybe my quest for a system is a typical civil law approach to law. In this contribution I will show how our system can be applied. I will leave it to the readers to judge if this approach is too complicated or boring, or if it helps in understanding European food law.

\section{B Structure}

Probably it is also typically 'civil law' to require there to be a system in the first place, for example to expect that the totality consisting of rules and unregulated aspects of the regime in question is comprehensive. To identify blank spots in this totality would be a relevant scholarly criticism in itself. Probably a common law approach only sees a role for the law after a problem has been identified and thus a common lawyer would be less surprised than a civil lawyer to find in law a patchwork of solved issues with many open issues in between, maybe even without much internal coherence between the solved issues. $^{7}$

The structure of European food law presented in this contribution does not at least not entirely - relate to a blueprint that has been applied in creating the legislation, but is superimposed on a situation that has grown organically. It

\footnotetext{
${ }^{5}$ Mary Ann Glendon, Michael Wallace Gordon and Paolo G Carozza, Comparative Legal Traditions in a Nutshell (2 $2^{\text {nd }}$ ed, 1999).

${ }^{6}$ Ibid 91.

${ }^{7}$ In the words of Peter Hay, Law of the United States: an Overview (2002) 10: 'The focus on precedent, this manner of "finding the law of the case," explains the common law lawyer's preoccupation with the facts of particular cases and distinguishes common law methodology significantly from the approach of civilian lawyers.'
} 
consists of the common features and typical characteristics identified through scholarly analysis of a mass of legislation.

Analysis of the law relating specifically to the food sector in the European Union reveals that the legislation mostly addresses one or more of three aspects: the product (food as such), the process (the handling of food in production and trade) and the presentation (the communication about food in labelling and advertisement). These three legislative approaches are embedded in provisions dealing with general principles and public powers.

Figure 1 Structure of EU Food Law

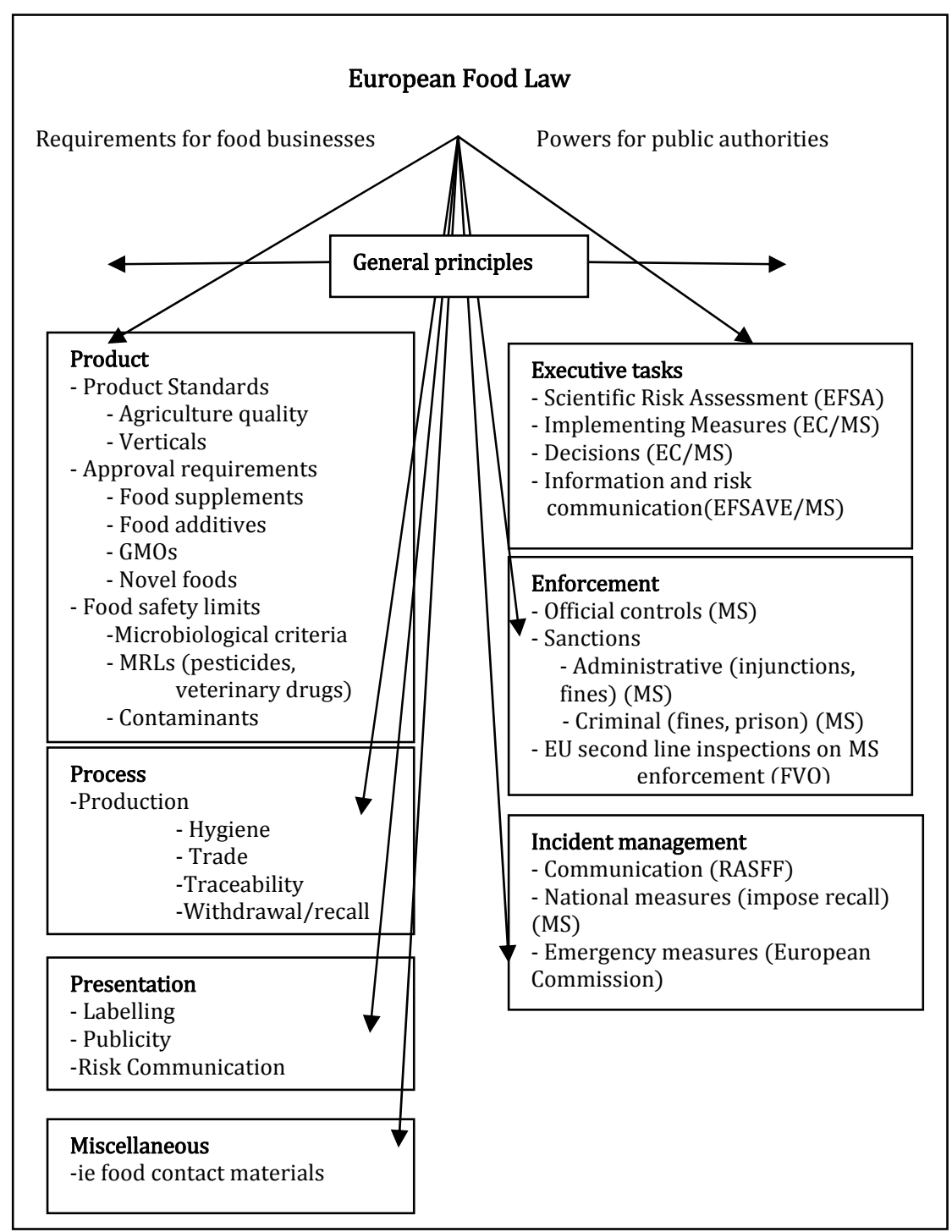


Figure 1 shows at the top the principles of European food law with, on the left-hand side, the provisions applicable to businesses and, on the right hand side, the provisions applicable to public authorities. An important aspect of EU food law not represented in this figure consists of institutional provisions, for example the creation of specialised authorities to deal with food related issues.

\section{Overview}

The structure represented in figure 1 determines the analysis of EU food law in this contribution. Part II of this article addresses the background of EU food law, such as its constitutional framework, institutional framework, human rights dimension and history. Part III discusses general principles and concepts. Part IV is about legislation addressing the product, and is subdivided into vertical product standards (IVA), market access requirements (IVB) and food safety targets (IVC). Part V deals with process-focussed provisions: hygiene in VA and traceability in VB. Part VI is about presentation of food products in labelling. Parts VII and VIII deal with public powers: enforcement in Part VII and incident management in Part VIII. Part IX targets consumers. Their capacity to enforce food law mainly derives from product liability law. Part X returns to the general principles of EU food law by discussing its foundation in risk analysis. Part XI concludes this contribution.

\section{BACKGROUND}

\section{A Constitutional Framework}

The European Economic Community (under its current name European Community (EC) now the most important element of the so-called European Union (EU)) was founded by the Treaty of Rome in 1957 (which entered into force on 1 January 1958). ${ }^{8}$ It is a supranational international organisation. The Member States have transferred some of their sovereignty to the Institutions of the EC with a view to achieving common goals. ${ }^{9}$

\footnotetext{
${ }^{8}$ Treaty Establishing the European Economic Community, signed 25 March 1957 (in force 1 January 1958).

${ }^{9}$ For a somewhat outdated but very accessible introduction to the system of EU law freely available on the Internet, see: Klaus-Dieter Borchardt, The ABC of Community law (2000), Luxembourg: Office for Official Publications of the European Communities $<$ http://www.okm.gov.hu/letolt/nemzet/law_abc.pdf > at 16 August 2009.
} 
First among these goals is the creation of an internal market of a type analogous to the market within one state.

Interestingly, the EC Treaty does not in itself provide a basis for food law. In consequence, legislation giving effect to EU food policy has been based on a combination of Treaty provisions, such as the provisions on agriculture ${ }^{10}$ and on the internal market ${ }^{11}$ in combination with the obligation to ensure in its policies a high level of protection of public health ${ }^{12}$ and to contribute to a high level of consumer protection. ${ }^{13}$

\section{B Institutional Framework}

\section{The $A B C$ of EU Food Law}

The 'ABC' of EU food law is its focus on Authorities, Businesses and Consumers. The three are, however, addressed in very different ways. While the protection of the life, health and other interests of consumers is the main objective of food law (see hereafter), EU food legislation does not provide consumers with any specific rights or remedies. Consumers who want to take legal action must rely on general consumer protection law such as product liability legislation (see Part 9). The key to food safety is in the hands of the businesses handling the food. The most important requirements regarding food are addressed to businesses. Obligations of public authorities - both at Community and at Member State level - are secondary to the obligations of businesses. Authorities have to ensure businesses' compliance and they have to deal with situations of non-compliance.

\section{EU Legislation}

EU legislation is a common product of the European Commission acting as day to day administrator of the Union - the Council of the European Union representing the Member States, and the European Parliament representing the people in the European Union. Within the European Commission, the Directorate-General (DG) Sanco (Health and Consumer Protection) is responsible for the domain of food law. It initiates legislation and it acts as executive.

\footnotetext{
${ }^{10}$ Consolidated version of the treaty establishing the European Community [2000] OJ C 325, arts 3(1)(e) and 33 (entered into force 1 February 2003)('EC Treaty').

${ }^{11}$ EC Treaty, art 95.

${ }^{12}$ EC Treaty, art 152.

${ }^{13}$ EC Treaty, art 153 .
} 
EC legislation comes in two major forms: regulations and directives. Regulations are comparable to legislation, like that known in virtually all countries that address their citizens directly in conferring rights and obligations on them. Directives address the legislatures of the Member States and serve the purpose of harmonising Member States' national legislation. Regulations are immediately applicable in all the Member States and, therefore, result in uniform law. Directives result in harmonised national legislation.

\section{$3 \quad$ Authorities}

Part of DG Sanco is the Food and Veterinary Office (FVO). The FVO is an inspection service that oversees national inspections, both within the European Union and in third countries wishing to export to the European Union, with the aim of ensuring that they perform up to EU standards.

The European Food Safety Authority (EFSA) is responsible for scientific risk assessment. It operates independently of the European Commission, which is responsible for risk management. It is independent in the sense that the Commission cannot give it instructions.

\section{$4 \quad$ Court of Justice}

The Court of Justice of the European Communities protects the uniform interpretation of EU law. It exercises several functions. It supports national courts in the Member States by providing preliminary rulings on matters regarding the interpretation of EU law, it hears actions for annulment of decisions taken by the EU institutions, and it judges behaviour of Member States brought before it by the European Commission in so-called infringement proceedings (alleged cases of non-compliance by Member States).

\section{$5 \quad$ Member States}

All powers (and the related responsibilities) that have not been expressly transferred to the Institutions remain with the Member States. There is no European police force. Member states are responsible for the enforcement of European law in general and European food law in particular.

The sovereignty of the Member States is recognised in, among other things, the so-called principle of institutional autonomy. EU law has little to say about the organisation of the public sector in the Member States. Usually, 
obligations in regulations or directives are conferred on the national 'competent authority'. It is for the national legislature to decide which state organ will be the competent authority in any given matter and to endow it with the powers necessary to fulfil its obligations under EU law. In most Member States food law is in the domain of either the minister of agriculture or the minister of public health. Most Member States also have a more or less independent food safety authority.

\section{Human Rights Dimension}

All EU Member States are also among the members of the Council of Europe $^{14}$ and, as such, are state parties to the European Convention on Human Rights and Fundamental Freedoms and to the European Social Charter. They are also state parties to the UN human rights treaties: the International Convention on Civil and Political Rights ${ }^{15}$ and - from a food perspective most important - the International Covenant on Economic, Social and Cultural Rights. ${ }^{16}$ The European Union has its own Charter of Fundamental Rights. ${ }^{17}$

Despite the emphasis that the European Union lays on respect for human rights by its Member States, in EU food law human rights consciousness is almost totally absent. ${ }^{18}$ Nowhere does the EU legislature express the opinion that, in ensuring the safety of food, it is living up to human rights obligations. ${ }^{19}$ Nor does it give account of the fact that its labelling legislation limits freedom of expression and should thus conform to the applicable limitation clauses in the human rights treaties. ${ }^{20}$

\footnotetext{
${ }^{14}$ See generally, Council of Europe (2009) < http://www.coe.int/ > at 16 August 2009.

${ }^{15}$ Opened for signature 16 December, 1966, 999 UNTS 171 (in force 23 March, 1976).

${ }^{16}$ Opened for signature 16 December 1966, 993 UNTS 3 (in force 3 January, 1976).

${ }^{17}$ [2000] OJ C 364/1.

${ }^{18}$ German scholars sometimes raise freedom of speech issues. So far I have not seen this being taken up in international debate.

${ }^{19}$ For a discussion of a similar lack in human rights consciousness in one of the EU Member States, see, Otto Hospes and Bernd van der Meulen (eds), Fed Up with the Right to Food? The Netherlands' Policies and Practices Regarding the Human Right to Adequate Food (2009). See $<$ http://www.wageningenacademic.com/righttofood $>$.

${ }^{20}$ Unlike US food law, where labelling legislation occurs in the context of the First Amendment. See, for example: Edward M Basile and Melanie Gross, 'The First Amendment and Federal Court Deference to the Food and Drug Administration: The Times They Are AChangin' (2004) 59 Food and Drug Law Journal. 31.
} 


\section{Development}

\section{Introduction}

From its beginning, the European Economic Community devoted much of its attention to agriculture. Initial motivators were the desire to gain selfsufficiency and to support the rural areas and their agricultural population. Almost from the start legislation developed which addressed food as a commodity in its own right. ${ }^{21}$ At first this legislation originated from the Directorate General (DG) responsible for agriculture, but emphasis shifted to the DGs responsible for industry, enterprises and the internal market.

From the early 1960s until the eruption of the BSE crisis in the mid-1990s, European food law was principally directed at the creation of an internal market for food products in the EU. This market-oriented phase can be divided into two stages. During the first, emphasis was on harmonisation through vertical directives. This stage ended with case law of which the 'Cassis de Dijon' judgment is the most famous. ${ }^{22}$ During the second stage emphasis shifted to harmonisation through horizontal directives. ${ }^{23}$

The BSE crisis and other food scares in the 1990s brought to light many serious shortcomings in the existing body of European food law. It became evident that fundamental reforms would be needed. In January 2000 the European Commission announced its vision for the future development of European food law in a White Paper on Food Safety. ${ }^{24}$ It emphasised the Commission's intent to change its focus in the area of food law from the development of a common market to assuring high levels of food safety. In the years since its publication, a complete overhaul of European food legislation has taken place.

\footnotetext{
${ }^{21}$ It took some decades, however, before food law developed as an academic specialisation. The European Council for Agricultural Law (CEDR: Comité Européen de Droit Rurale: $<$ www.cedr.org $>$ ), for example, was established in 1957. The European Food Law Association (EFLA: < www.efla-aeda.org >) was established in 1973.

${ }^{22}$ Rewa-Zentral AG v Bundesmonopolverwaltung für Branntwein (C-120/78) [1979] I-649.

${ }^{23}$ The distinction between horizontal and vertical directives will be discussed below.

${ }^{24} \operatorname{COM}(1999) 719$ def. Commission White Papers traditionally contain proposals for Community action in specific areas and are developed in order to launch consultation processes at the European level. If White Papers are favorably received by the Council they often form the basis of later 'Action Programs' to implement their recommendations.
} 


\section{Creating an Internal Market for Food in Europe}

When the six original members of what is today the European Union signed the Treaty of Rome in 1957, they created a community with an economic character. This was reflected not only in its original name - the European Economic Community - but also in the original objective of creating a common market.

At the heart of the instruments formulated to achieve this objective are the socalled four freedoms of the European Union: the free movement of labour, the free movement of services, the free movement of capital and the free movement of goods. The free movement of goods ${ }^{25}$ has been vital to the development of food law.

During the first years of implementing the ambitious idea of trade without frontiers, Community legislation aimed primarily at facilitating the internal market through the harmonisation of national standards. Agreement about the quality and identity of food products was considered necessary. To reach such agreement directives were issued on the composition of certain specific food products. This is called vertical ('recipe', 'compositional' or 'technical standards') legislation. Vertical legislation resembles the product standards of the Codex Alimentarius. ${ }^{26}$

Early attempts to establish a common market for food products in Europe by prescribing harmonised product compositions faced two substantial obstacles. Firstly, at that time all legislation required unanimity in the Council, which gave each Member State a virtual right of veto over new legislation. Secondly, there was the sheer scale of the task. There are, as the Community Institutions soon realised, simply too many food products to deal with. Nevertheless, quite a few products remain subject to European rules on compositional standards. ${ }^{27}$ These compositional standards form the legacy of the first phase of EU food law. They are being updated or replaced when necessary but no new products are being added.

\section{Advancement through Case Law}

It was the Court of Justice that showed the way out of the deadlock through new, broad, interpretations of the key provision on the free movement of

\footnotetext{
${ }^{25}$ See EC Treaty, arts 3(1)(c) and 23-31.

${ }^{26}$ See below Part IIIC.

${ }^{27}$ For example, sugar, honey, fruit juices, milk, spreadable fats, jams, jellies, marmalade, chestnut puree, coffee, chocolate, natural mineral waters, minced meat, eggs and fish. Wine legislation is a body of law in itself.
} 
goods in the common market: article 28 of the EC Treaty. ${ }^{28}$ This article prohibits quantitative restrictions on imports and all measures having equivalent effect. ${ }^{29}$ It should be read in connection with article 30 of the EC Treaty which lists possible exceptions to the free movement of goods, such as the protection of health and life of humans, animals or plants.

The landmark decision in this context was Cassis de Dijon. ${ }^{30}$ A German chain of supermarkets sought to import Cassis de Dijon, a fruit liqueur, from France. The German authorities, however, refused to authorise the import because the alcohol content was lower than that required by German national law, which stipulated that such liqueurs should contain at least 25 per cent alcohol. Cassis de Dijon contained just 20 per cent alcohol.

The German authorities acknowledged that this was a restriction on trade, but sought to justify it on the basis that beverages with too little alcohol pose several risks. The German authorities argued that alcoholic beverages with low alcohol content could induce people to develop tolerances to alcohol more quickly than beverages with higher alcohol content, and that consumers trusting the (German) law might feel cheated if they purchased such products with the expectation of higher alcohol content. Finally, Germany submitted that, in the absence of such a law, beverages with low alcohol content would benefit from an unfair competitive advantage because taxes on alcohol are high, and beverages with lower alcoholic content would be saleable at significantly lower prices than products produced in Germany according to German law.

The Court held that the type of arguments presented by the German authorities would be relevant, even where they did not come under the specific exceptions contained in the EC Treaty, provided that those arguments met an urgent need. This is known as the rule of reason. The Court found that Germany's public health argument did not meet this standard of urgency. The Court specifically cited the availability of a wide range of alcoholic beverages on the German market with alcohol content of less than 25 per cent. As to the risk of consumers feeling cheated by lower than expected alcohol content, the Court suggested that such a risk could be eliminated with less effect on the common market by displaying the alcohol content on the beverage's label.

\footnotetext{
${ }^{28}$ At that time numbered article 30 .

${ }^{29}$ On the relevance of art 25 EC Treaty, banning customs duties and charges having equivalent effect, see Morten P Broberg, Transforming the European Community's Regulation of Food Safety Swedish Institute for European Policy Studies (2008:5)[2.3] and [2.4]: $<$ http://www.sieps.se/en/research/effekter-av-eus-politik/the-food-policy-of-the-europeanunion.html $>$ at 18 October 2009.

${ }^{30}$ Rewa-Zentral AG v Bundesmonopolverwaltung für Branntwein (C-120/78) [1979] I-649.
} 
For cases such as this one, in which there are no specific justifications for restrictions on the trade between Member States, the Court introduced a general rule: products that have been lawfully produced and marketed in one of the Member States may not be kept out of other Member States on the grounds that they do not comply with the national rules. This is called the principle of mutual recognition.

With its ruling the Court in Luxemburg laid the legal foundation for a wellfunctioning common market.

Several commentators expressed concern that the principle of mutual recognition would lead to product standards based on the lowest common denominator. It is clear that manufacturers established in Member States with the most lenient safety or technical requirements or legal procedures do gain a competitive advantage.

The limitations and drawbacks of the principle of mutual recognition highlighted the need for further harmonisation of food requirements at the European level. For Member States with more stringent national standards, European-level legislation became the best hope for raising neighbours' standards. The Cassis de Dijon ruling marked a significant change in the perception of the benefits of harmonisation. Before Cassis, harmonisation was seen merely as a condition for the functioning of the internal market. Afterwards, emphasis shifted to the need to alleviate the consequences of the internal market. In legal terms, too, the wave of harmonisation that followed Cassis differed from earlier efforts. Emphasis shifted from product-specific legislation to horizontal legislation, meaning general rules addressing common aspects for a broad range of foodstuffs.

\section{$4 \quad$ Breakdown}

The heyday of market-oriented food law based on mutual recognition ended in tears. The food and agricultural sectors in the European Union emerged deeply traumatised from the 1990s. A series of crises resulted in a breakdown of consumer confidence in public authorities, industry and science. The current third phase of EU food law can only be truly fathomed if the trauma to which it responds is understood.

Although the bovine spongiform encephalopathy (BSE) crisis was not the first and, in terms of death toll, not the worst ${ }^{31}$ food safety crisis in the European

\footnotetext{
${ }^{31}$ See Abaitua Borda I et al, 'Toxic Oil Syndrome Mortality: The First Thirteen Years' (1998) 27(6) International Journal of Epidemiology 1057; Emilio Gelpí et al, 'The Spanish Toxic Oil Syndrome Twenty Years after Its Onset: A Multidisciplinary Review of Scientific
} 
Union, it caused an earthquake in the legal and regulatory landscape of Europe. Subsequent food safety scares, ${ }^{32}$ outbreaks of animal diseases ${ }^{33}$ and scandals over fraudulent practices, added to a sense that protective measures should be taken as a matter of urgency.

Public awareness of the BSE-epidemic, and the time it had taken British and European authorities to address it, presented a major challenge to European cooperation in the area of food safety. When the extent of the crisis became public, the European Union issued a blanket ban on British beef exports. In response, Britain adopted a policy of non-cooperation with the European institutions, and sought to deny the extent and seriousness of the BSE problem. ${ }^{34}$

The European Parliament played a crucial role in defusing this crisis. A temporary Enquiry Committee was instituted to investigate the actions of the national and European agencies involved in the crisis. ${ }^{35}$ The Enquiry Committee presented its report in early $1997 .{ }^{36}$ The report strongly criticised the British government as well as the European Commission. The

Knowledge' (2002) 110(5) Environmental Health Perspectives 457. It was found that the toxic oil syndrome (TOS) epidemic that occurred in Spain in the spring of 1981 caused approximately 20,000 cases of a new illness. Researchers identified 1,663 deaths between 1 May 1981 and 31 December 1994 among 19,754 TOS cohort members. Mortality was highest during 1981. The poisoning was caused by fraud consisting of mixing vehicle oil with oil for human consumption.

${ }^{32}$ One example is the Belgian dioxin crisis. It was caused by industry oil that had found its way into animal feed and subsequently into the food chain (Craig Whitney, 'Food Scandal Adds to Belgium's Image of Disarray', New York Times (New York), 9 June 1999, A4). Another example is the introduction of medroxyprogesterone acetate (MPA) into pig feed in 2002 (James Graff, 'One Sweet Mess' (2002) Time, July 21, 2002 $<$ www.time.com/time/nation/article/0,8599,322596,00.htm > at 16 August 2009.) Sugar discharges from the production of MPA, a hormone used in contraceptive and hormone replacement pills, were used in pig feed and by that route MPA entered the food chain. In 2004 a dioxin crisis broke out in the Netherlands.

${ }^{33}$ Such as Foot and Mouth Disease, SARS and Avian Influenza.

${ }^{34}$ The TV footage where the responsible Secretary of State, John Gummer, is shown feeding his little daughter a hamburger to convince the public that nothing was wrong with British beef became symbolic. See, BBC, 'Gummer enlists his daughter in BSE fight', $B B C$ News, 16 May 1990

$<$ http://news.bbc.co.uk/onthisday/hi/dates/stories/may/16/newsid_2913000/2913807.stm > at 16 August 2009.

${ }^{35}$ Decision setting up a temporary committee of inquiry [1996] OJ C 261/132.

${ }^{36}$ Temporary Committee of Inquiry into BSE, European Parliament, Report on the Alleged Contraventions or Maladministration in the Implementation of Community Law in Relation to BSE (1997), A4-0020/97/A, PE 220.544/fin/A: < http://www.mad-cow.org/final_EU.html > at 18 October 2009. The report is often referred to by the name of the chairman of the Enquiry Committee, namely as the Ortega Medina report. 
Commission was accused of wrongly putting industry interests ahead of public health and consumer safety; science had been biased, and transparency had been lacking.

Paradoxically, this reproachful report, followed by a motion of censure proposed to the European Parliament, provided the Commission with the impetus it had hitherto lacked. Indeed it provided it with a window of opportunity to take the initiative for restructuring European food law in a way that considerably strengthened its own powers. The Commission undertook far-reaching commitments to implement the Committee's recommendations.

As early as May 1997, the Commission published a Green Paper on the general principles of food law in the EU. ${ }^{37}$ It sketched the outlines of a legal system capable of getting a firm grip on food production. Consumer protection was made the main priority. The Commission committed itself to strengthening its food safety control function. This led directly to the establishment of the Food and Veterinary Office (FVO) in Dublin in 1997. Furthermore, the Commission announced the establishment of an independent food safety authority. ${ }^{38}$ The Commission kept the pressure on beyond 1997 , eventually gaining the support of the European Court of Justice for the measures that had been taken against Great Britain at the climax of the crisis. $^{39}$

On 12 January 2000 the Commission published its famous White Paper on Food Safety. ${ }^{40}$

\section{$5 \quad$ The White Paper: A New Vision on Food Law}

The Commission's vision on the future shape of EU food law was laid down in the White Paper on Food Safety. Before the BSE crisis, European food safety law was subordinated to the development of the internal market. The

\footnotetext{
${ }^{37}$ Commission Green Paper on the General Principles of Food Law in the European Union, $\operatorname{COM}(1997) 176$.

${ }^{38}$ European Commission, Communication of the European Commission: Consumer Health and Food Safety (1997) COM(97) 183 fin of 30 April 1997

$<$ http://ec.europa.eu/food/fs/sc/comeclen.pdf $>$ at 18 August 2009.

${ }^{39}$ See The Queen $v$ Ministry of Agriculture, Fisheries and Food, ex parte National Farmers Union (C-157/96) [1998] ECR I-02211; United Kingdom of Great Britain and Northern Ireland v Commission of the European Communities (C-180/96) [1996] ECR I-03903; United Kingdom v Commission of the European Communities (C-209/96) [1998] ECR I-5655.

${ }^{40} \operatorname{COM}(1999) 719$ final. Unlike a Green Paper that is intended mostly as a basis for public discussion a White Paper contains concrete policy intentions.
} 
shortcomings in the handling of the crisis clearly revealed a need for a new, integrated approach to food safety.

The Commission aimed to restore and maintain consumer confidence. The White Paper focused on a review of food legislation in order to make it more coherent, comprehensive and up-to-date, and to strengthen enforcement.

Part of the package was the envisaged establishment of a new European Food Safety Authority, ${ }^{41}$ to serve as the scientific point of reference for the whole Union, and thereby contribute to a high level of consumer health protection.

Implementing the Vision

The Annex to the White Paper is the 'Action Plan on Food Safety', a list of 84 legislative steps that the Commission deemed necessary to create a regulatory framework capable of ensuring a high level of protection of consumers and public health.

The turn of the millennium saw the beginning of the planned overhaul of European food law and, in the few years that have since passed, most of the 84 steps have been taken. The new regulatory framework is based on regulations rather than directives.

\section{$7 \quad$ EU Food Law in the $21^{\text {st }}$ Century}

Only two years after the White Paper was published, the cornerstone of new European food law was laid: Regulation 178/2002 of the European Parliament and of the Council of 28 January 2002 laying down the general principles and requirements of food law, establishing the European Food Safety Authority and laying down procedures in matters of food safety. ${ }^{42}$ This regulation is often referred to in English as the 'General Food Law' ('GFL'). The Germans speak of it as a Basisverordnung (Basic Ordinance) - perhaps a more precise phrase given that the regulation is in fact the basis upon which European and national food laws are now being re-constructed. ${ }^{43}$ The main objective of the General Food Law is to secure a high level of protection of

\footnotetext{
${ }^{41}$ In the White Paper the Commission speaks of a European Food Authority. The word 'safety' was inserted later.

42 [2002] OJ L 31/1.

${ }^{43}$ New European food law displays several characteristics in which it is different from its predecessor: more emphasis on horizontal regulations (rather than on vertical legislation); more emphasis on regulations that formulate the goals that have to be achieved (so-called objective regulations) than on means regulations; and increased use of regulations (rather than directives) and thus increasing centralisation.
} 
public health and consumer interests with regard to food products. It does so by stating general principles, establishing the European Food Safety Authority and giving procedures to deal with emergencies.

After the General Food Law, whole packages of new legislation followed (Figure 2).

Figure 2 Highlights in the overhaul of EU food law.

\begin{tabular}{|l|l|}
\hline 2002 & Regulation 178/2002: GFL \\
\hline 2003 & Regulations 1829/2003 and 1830/2003: GMO package \\
\hline $2004 / 2005$ & Regulations 852-854/2004: Hygiene package \\
\hline & Regulation 882/2004: Official controls \\
\hline & Regulation 1935/2004: Food contact materials \\
\hline $2006 / 2007$ & Regulation 1924/2006: Nutrition and health claims \\
\hline 2007 & $\begin{array}{l}\text { White Paper: A Strategy for Europe on Nutrition, Overweight } \\
\text { and Obesity Related Health Issues }\end{array}$ \\
\hline 2008 & $\begin{array}{l}\text { Regulations 1331-1334/2008 on additives, flavourings and } \\
\text { enzymes }\end{array}$ \\
\hline Ongoing & Obesity policy \\
\hline & Modernisation of pesticides legislation \\
\hline & Modernisation of legislation on novel foods \\
\hline & Modernisation of labelling legislation \\
\hline
\end{tabular}

The most pressing issue on the agenda for the years to come is probably the issue of overweight and obesity. So far the EU legislator has not found suitable instruments to deal with this problem. Measures are currently limited to providing consumers with information, both directly and on food product labels.

\section{General Concepts and Principles}

\section{A Scope}

The General Food Law defines the scope of food law. Its approach is holistic in the sense that 'food law' applies to all businesses in the food chain, 'from farm to fork' including feed for food-producing animals. In principle, food law applies to the primary sector, but some exemptions are in place, in particular regarding hygiene requirements. 
The General Food Law provides a definition of 'food' in article $2 .{ }^{44}$ Fulfilment of the criteria in the definition is a precondition for the applicability of the GFL. If a product meets this definition it is a food in the sense of the GFL and the GFL applies to it. The same holds true for all the other laws and regulations that use this definition. In due course that should be the whole body of food law in the European Union and its Member States. The definition reads as follows:

'Food' (or 'foodstuff') means any substance or product, whether processed, partially processed or unprocessed, intended to be, or reasonably expected to be ingested by humans. 'Food' includes drink, chewing gum and any substance, including water, intentionally incorporated into the food during its manufacture, preparation or treatment. (...) 'Food' shall not include: (a) feed; (b) live animals unless they are prepared for placing on the market for human consumption; (c) plants prior to harvesting; (d) medicinal products (...) (e) cosmetics (...) (f) tobacco and tobacco products (...) (g) narcotic or psychotropic substances within the meaning of the United Nations Single Convention on Narcotic Drugs, 1961, and the United Nations Convention on Psychotropic Substances, 1971; (h) residues and contaminants.

Unlike the position under US food law, the concept of 'food' does not include animal feed. The US categorisation of humans as animals (in its reference to 'articles used for food or drink for man or other animals ${ }^{45}$ ) would conflict with European culture. The animal feed chain is brought within the ambit of EU food law by separate provisions and definitions in the General Food Law.

\section{B Objectives}

The General Food Law expresses the objectives of EU food law in article 5:

1. Food law shall pursue one or more of the general objectives of a high level of protection of human life and health and the protection of consumers' interests, including fair practices in food trade, taking account of, where appropriate, the protection of animal health and welfare, plant health and the environment.

\footnotetext{
${ }^{44}$ Surprisingly, although the European legislator had been very active in the field of food law, the term 'food' was for the first time defined in the 2002 General Food Law (GFL). The GFL does not distinguish between food and food ingredients as some older legislation does. Ingredients fulfil the definition of food and are therefore subject to the same safety rules. Only in labelling legislation does the distinction still have significance.

${ }^{45}$ Federal Food, Drug, and Cosmetic Act, 21 USC $§ 201$ (f) (2008).
} 
2. Food law shall aim to achieve the free movement in the Community of food and feed manufactured or marketed according to the general principles and requirements in this Chapter.

So far this provision has provoked little discussion. Taken literally, it could be interpreted to mean that other interests such as those of (individual) food businesses and of the food sector as a whole may not be taken into account. Subsequent legislation does not, however, reflect such limitation. The main message, therefore, does not seem to be about excluding certain interests, but about focusing on the protection of consumers. ${ }^{46}$

\section{Principles}

The General Food Law explicitly labels as a 'principle' the requirement that food law protecting human health should be based on risk analysis, ${ }^{47}$ thus on science. No doubt discussions within the WTO regarding the EU approach to growth-promoting hormones and genetically modified foods have contributed to the decision to make food law (more) science-based. For situations of scientific uncertainty the precautionary principle applies. ${ }^{48}$ That is to say, when risk assessment is inconclusive but gives scientific reasons to suspect a food safety risk, public authorities are entitled to base protective measures on a worst case scenario.

The question of what the principle (that EU food law must be science-based) means in practice is discussed in Part X.

\section{Another principle is that}

[w] here international standards exist or their completion is imminent, they shall be taken into consideration in the development or adaptation of food law, except where such standards or relevant parts would be an ineffective or inappropriate means for the fulfilment of the legitimate objectives of food law or where there is a scientific justification, or where they would result in a different level of protection from the one determined as appropriate in the Community. ${ }^{49}$

\footnotetext{
${ }^{46}$ On this issue see: Bernd van der Meulen, Reconciling Food Law to Competitiveness. Report on the Regulatory Environment of the European Food and Dairy Sector (2009). See $<$ http://www.wageningenacademic.com/reconciling $>$.

${ }^{47}$ General Food Law, art 6.

${ }^{48}$ General Food Law, art 7.

${ }^{49}$ General Food Law, art 5(3).
} 
This principle is reflected, for example, in the definition of 'food' which is based on the food definition in the Codex Alimentarius. ${ }^{50}$

The Codex Alimentarius is a set of international standards, guidelines and recommendations regarding food, its production and its safety. The texts of the Codex were developed by a Commission established by the Food and Agriculture Organisation of the United Nations (FAO) and the World Health Organisation (WHO) ${ }^{51}$ Virtually all states of the world are represented in the Codex Alimentarius Commission. For comparative food law, this makes the Codex very useful as benchmark.

\section{Product Focused Provisions}

Regarding food products, the EU legislature follows two different approaches. German scholars label these as the 'abuse principle' and the 'prohibition principle' respectively. ${ }^{52}$

It is a basic requirement in EU food law that food may not be brought to the market if it is unsafe.$^{53}$ It is the responsibility of food businesses to judge on a case by case basis whether this requirement is met. ${ }^{54}$ Infringements may set off enforcement activities. If no other requirement applies, the business is free to come to the market but may suffer consequences if it abuses this liberty. This is the abuse principle.

For some hazards the legislator defines acceptable levels (food safety targets), thus distinguishing safe foods from unsafe foods. See Part IVC of this article.

For some food categories it is required that the safety is proven to the satisfaction of the authorities before the food may be brought to the market.

50 See Codex Alimentarius Commission, Procedural Manual (1 $7^{\text {th }}$ ed, Rome, 2007) 40 Definitions for the Purposes of the Codex Alimentarius: 'For the purposes of the Codex Alimentarius: Food means any substance, whether processed, semi-processed or raw, which is intended for human consumption, and includes drink, chewing gum and any substance which has been used in the manufacture, preparation or treatment of "food" but does not include cosmetics or tobacco or substances used only as drugs.'

${ }^{51}$ See: < http://www.codexalimentarius.net/web/index_en.jsp > at 2 November 2009.

${ }^{52} \mathrm{M}$ Will and D Guenther, Food Quality and Safety Standards, as Required by EU Law and the Private Industry. With special reference to the MEDA countries' exports of fresh and processed fruits \& vegetables, herbs \& spices: A Practitioners' Reference Book ( $\left.2^{\mathrm{nd}} \mathrm{ed}, 2007\right)$ $<$ http://www2.gtz.de/dokumente/bib/07-0800.pdf > at 18 August 2009.

${ }^{53}$ General Food Law, art 14.

${ }^{54}$ General Food Law, art 17(1). 
Before authorisation is obtained a prohibition applies. To these foods the prohibition principle applies. See Part IVB.

Some older legislation goes beyond safety requirements and defines all the kinds of properties and quality aspects that a food must fulfil. See Part IVA.

\section{A Product Standards}

In the early stages of development of EU food law and of the common agricultural policy, emphasis was on product-specific legislation.

The common agricultural policy initially set out to ensure self-sufficiency of the European Community and decent living conditions for the rural population. An important instrument in this context was that of price guarantees. The EC would buy all products that were not sold in the market at a set price. To ensure the quality of the produce bought under this regime, quality requirements were set for fresh fruit and vegetables brought to the EU market.

As described above, to create a common market for food products, attempts were made to agree on common definitions of requirements for food products. The success of this approach was limited and further attempts were abandoned after the European Court of Justice developed an alternative way to come to a common market: the principle of mutual recognition.

The EC Court of Justice is reluctant to accept product standards set by Member States if they are applied to keep products originating in other Member States out of the market. The Court checks such product standards for proportionality: for example, have they been set for a legitimate purpose and are they the least restrictive measure to achieve that purpose? The litmus test is whether the same objective cannot be achieved by labelling, that is, by informing the consumer of the presence or absence of the properties of the product provided for in the standard. In this way we witness a shift from product-focused requirements to labelling requirements.

In so far as product-specific provisions still exist, the legally defined names must be used on the label and these names may not be used if the legal standard has not been met. ${ }^{55}$ For example a product may generally not be called chocolate if it consists of less than 35 per cent of cocoa. ${ }^{56}$

\footnotetext{
${ }^{55}$ While I am writing this line (6 May 2009) a radio commercial makes fun of this legislation by stating that it would be illegal to call the manufacturer's product a 'jam' because it has less
} 


\title{
B Market Access Requirements
}

Conventional foods may freely be brought to the EU market. From the early 1960s systems of premarket approval requirements have been introduced for synthetic substances added to food for technological reasons. These are the so-called food additives. An additive is

\begin{abstract}
any substance not normally consumed as a food in itself and not normally used as a characteristic ingredient of food, whether or not it has nutritive value, the intentional addition of which to food for a technological purpose in the manufacture, processing, preparation, treatment, packaging, transport or storage of such food results, or may be reasonably expected to result, in it or its by-products becoming directly or indirectly a component of such foods. ${ }^{57}$
\end{abstract}

The concept of additive includes sweeteners and colours. The system is based on so-called positive lists. That is to say, additives that have been approved for use in food are included in a list. Only those additives may be used in food that are mentioned on the list and comply with the list's requirements. All other substances that fulfil the definition of additive are forbidden. Additives are included in the list under an 'E-number'. This number may be used to declare the additive in the list of ingredients on the food product concerned.

The system of positive lists has gradually been expanded to include other categories of foods that are considered potentially hazardous. Among these are novel foods - foods that were not consumed in the EU before 1997. Initially the concept of novel food included genetically modified foods. As from 2004, however, these form a separate category with separate legislation.

Approval schemes vary. A common aspect is that a food which is subject to approval may only be brought to the market after it has been approved on the basis of a scientific risk assessment. Other criteria for approval are that the food must not mislead the consumer and must not be nutritionally disadvantageous compared with a conventional food that it will replace. For

than 60 per cent sugar. The hope is expressed that the manufacturer will not be prosecuted for being too healthy.

${ }^{56}$ See for details and exceptions: Directive 2000/36/EC of the European Parliament and of the Council of 23 June 2000 relating to cocoa and chocolate products intended for human consumption [2000] OJ L 197/19.

${ }^{57}$ Regulation (EC) No 1333/2008 of the European Parliament and of the Council of 16 December 2008 on food additives [2008] OJ L 354/16, art 3(2)(a). Note that this concept of food additives is much narrower than the one applied in the USA. See Federal Food, Drug, and Cosmetics Act, 21 USC $\S 201$ (2008). 
additives, there is the additional criterion that they must fulfil a technological need.

With regard to genetically modified organisms, American scholars sometimes maintain that the American approach focuses on the product and the European approach focuses on the process. It is true that the process of genetic modification brings a food within the ambit of the approval requirements, but it is the product that results from the process, not the process as such whose safety is assessed.

The approval of food additives is generic. If an additive is included in the list, every business is entitled, from a food law point of view (though intellectual property rights may decree otherwise), to bring it to the European market. For other foods such as GMOs the approval is specific. This means that the approval authorises the applicant exclusively to bring the product to the market. If other businesses want to bring the same product to the market, they need an approval as well. At the time of writing, the Novel Foods Regulation is under revision. The European Commission has proposed to shift its regime from specific to generic. This is in particular important for the so-called exotic foods. These are foods that have no history in the European Union and are thus considered novel, but that are traditional in other parts of the world.

\section{Food Safety Targets}

Finally there is legislation setting limits to the presence of undesirable substances (contaminants, toxins, residues of pesticides or veterinary drugs) or organisms in food. ${ }^{58}$ The limits are set on the basis of scientific risk assessment. To products that have not been approved, or for which no lowest safety level can be established, a zero tolerance may apply.

\footnotetext{
${ }^{58}$ See, for example, Council Regulation (EEC) No 315/93 of 8 February 1993 laying down Community procedures for contaminants in food [1993] OJ L 37; Commission Regulation (EC) No 1881/2006 of 19 December 2006 setting maximum levels for certain contaminants in foodstuffs [2006] OJ L 364/5; Commission Regulation (EC) No 2073/2005 of 15 November 2005 on microbiological criteria for foodstuffs [2005] OJ L 338; Regulation (EC) No 396/2005 of the European Parliament and of the Council of 23 February 2005 on maximum residue levels of pesticides in or on food and feed of plant and animal origin and amending Council Directive 91/414/EEC [2005] OJ L 70/1; Council Regulation (EEC) No 2377/90 of 26 June 1990 laying down a Community procedure for the establishment of maximum residue limits of veterinary medicinal products in foodstuffs of animal origin [1990] OJ L 22/1; Council Directive 96/22/EC of 29 April 1996 concerning the prohibition on the use in stockfarming of certain substances having a hormonal or thyrostatic action and of $\beta$-agonists, and repealing Directives 81/602/EEC, 88/146/EEC and 88/299/EEC [1996] OJ L 125/3.
} 


\section{Process-Focused Provisions}

It has been realised that, in order to ensure food safety, both trade and also the processes of production must be under control. Practices aimed at the prevention of food safety risks are known as 'hygiene'. At the heart of EU legislation on food hygiene is the so-called HACCP-system: Hazard Analysis and Critical Control Points. ${ }^{59}$ This system requires food businesses to make such an analysis of their processes that they know where hazards may occur, how to recognise them and how to deal with them in order to maintain food safety. Application of the system must be well documented.

In trade a requirement of traceability applies. ${ }^{60}$ Food businesses must record where their inputs come from and where their products go. If a food safety incident occurs this information must enable the authorities to swiftly identify the origin of the problem and its dispersal in order to eliminate the cause and take care of the consequences.

Finally, businesses that have reason to believe that a food they have brought to the market may not be in conformity with food safety requirements are under an obligation to withdraw it from the food chain and recall it from consumers. ${ }^{61}$

\section{A Processing}

The HACCP system was developed by the American space agency NASA to ensure that astronauts would not suffer from diarrhoea, vomiting, food poisoning or other food-borne hazards during their stay in outer space. It has been adopted by the Codex Alimentarius Commission as a system suitable to ensure food safety worldwide. Part of the system was in place in the European Union before 2006, but as of 1 January 2006 the entire system applies to all food businesses in the EU with the exception of the primary sector and some traditional producers. ${ }^{62}$

\footnotetext{
${ }^{59}$ See, Regulation (EC) No 852/2004 of the European Parliament and of the Council of 29 April 2004 on the hygiene of foodstuffs [2004] OJ L 139/1.

${ }^{60}$ General Food Law, art 18.

${ }^{61}$ General Food Law, art 19.

${ }^{62}$ At least in public law an exception applies. Primary producers following private standards such as GlobalGAP have to implement HACCP.
} 


\section{B Trade}

Traceability is required of all food businesses in the European Union. The concept of traceability is defined as

... the ability to trace and follow a food, feed, food-producing animal or substance intended to be, or expected to be incorporated into a food or feed, through all stages of production, processing and distribution. ${ }^{63}$

The aim of traceability is to be able to quickly identify the source of a food safety problem and to conduct well aimed recalls in order to take affected products from the market. If no other, more specific, requirements apply based on this provision, businesses must be able to trace their inputs and outputs one step up and one step down.

For some product groups, such as GMOs ${ }^{64}$ and beef, ${ }^{65}$ an obligation to have available an intact paper trail applies.

\section{Presentation}

A major part of food legislation addresses the information regarding their product that food businesses provide to consumers through advertising and mainly - labelling. The most important codification of these rules is to be found in Directive 2000/13 of the European Parliament and of the Council of 20 March 2000 on the approximation of the laws of the Member States relating to the labelling, presentation and advertising of foodstuffs: the socalled 'Labelling directive'. ${ }^{66}$ Labelling means 'any words, particulars, trademarks, brand name, pictorial matter or symbol relating to a foodstuff and placed on any packaging, document, notice, label, ring or collar accompanying or referring to such foodstuff'. Labelling must not be misleading.

\footnotetext{
${ }^{63}$ General Food Law, art 3(15).

${ }^{64}$ Regulation (EC) No 1830/2003 of the European Parliament and of the Council of 22 September 2003 concerning the traceability and labelling of genetically modified organisms and the traceability of food and feed products produced from genetically modified organisms and amending Directive 2001/18/EC [2003] OJ L 268/24.

${ }^{65}$ See for detail on this issue B M J van der Meulen and A A Freriks, “"Beastly Bureaucracy" Animal Traceability, Identification and Labeling in EU Law' (2006) Journal of Food Law and Policy 317-59.

${ }^{66}$ Directive 2000/13/EC of the European Parliament and of the Council of 20 March 2000 on the approximation of the laws of the Member States relating to the labelling, presentation and advertising of foodstuffs [2000] OJ L 109/29. A proposal for a modernisation of this legislation is currently in progress.
} 
All pre-packaged food products must be labelled in a language that is easily understood. Usually this means in the national language of the Member State. The legislation makes the type of information it addresses mandatory, restricted or forbidden. In other words: some messages must be given, some may only be given if certain conditions are met and some may never be given. To begin with the last ...

\section{A Forbidden Information}

First of all it is not allowed to mislead the consumer. ${ }^{67}$ Further, the labelling and advertisement may not attribute to any foodstuff the property of preventing, treating or curing a human disease, or refer to such properties. ${ }^{68} \mathrm{~A}$ claim may be made that a food supports health, but not that it cures disease. The ban on medicinal claims applies even in situations where their correctness is scientifically substantiated. A product claiming to cure is, by definition, a drug and not a food.

\section{B Mandatory Information}

There are about twelve required (mandatory) pieces of information, the most important of which are: the name under which the product is sold; the list of ingredients; the quantity of certain ingredients or categories of ingredients; the presence of allergens; in the case of pre-packaged foodstuffs, the net quantity; the date of minimum durability or, in the case of foodstuffs which, from the microbiological point of view, are highly perishable, the 'use by' date; and the name or business name and address of the manufacturer or packager, or of a seller established within the Community. The list of mandatory information closely resembles the list proposed by the Codex Alimentarius Commission. ${ }^{69}$

Specific labelling requirements demand that the presence of additives, novel ingredients and GMOs be mentioned on the label.

${ }^{67}$ Directive 2000/13/EC, art 2(1)(a); General Food Law, art 8(1)(c) and 16.

${ }^{68}$ Directive 2000/13/EC, art 2(1)(b).

${ }^{69}$ Codex General Standard for the Labelling of Prepackaged Foods, CODEX STAN 1-1985 (last amended in 2008). 


\section{Restricted Information}

In 2006 a new Regulation on nutrition and health claims was published. ${ }^{70}$ Nutrition claims must conform to the annex to this regulation. The annex states among other things that the expression "light' ${ }^{71}$ may be used only in the case of a reduction of at least 30 per cent of certain nutrients or energy. Health claims, for example claims about the effects of a certain food on health, must be approved and science-based. Foods bearing health claims are sometimes called 'functional foods'.

At present nutrition labelling, that is labelling mentioning the nutrients and energy present in food products, is voluntary except when a claim is made. ${ }^{72}$ Legislation is currently being drafted to make it mandatory.

The origin of a product must only appear on the label if omitting this information would mislead the consumer to a material degree.

Some designations of origin are protected. Regulation 510/2006 on agricultural indications establishes rules for the protection of certain designations of origin (PDO) and geographical indications (PGI) on agricultural products. The regulation provides opportunities for small-scale producers to use these quality symbols as a means of promoting their products, without the long and costly process of obtaining a trade mark for their product. To a certain extent these quality symbols are comparable to collective trade marks in the sense that they can be used by a group of producers to distinguish their product. Member states may not introduce additional schemes of this type. ${ }^{73}$ Products from outside the EU can be brought under the ambit of the scheme.

Regulation 509/2006 $6^{74}$ has introduced a register of recognised traditional specialties. To obtain the TSG (Traditional Speciality Guaranteed) designation a product must possess features that distinguish it from other products, and it must be traditional.

${ }^{70}$ Regulation (EC) No 1924/2006 of the European Parliament and of the Council of 20 December 2006 on nutrition and health claims made on foods [2006] OJ L 404/9.

${ }^{71}$ In the EU for products with reduced energy the expression 'light' is preferred over the expression 'diet' because the latter is associated with illness.

${ }^{72}$ Council Directive 90/496/EEC of 24 September 1990 on nutrition labelling for foodstuffs [1990] OJ L 276/50.

${ }^{73}$ Commission v France (Free movement of goods) (C-6/02) [2003], protected designations of origin may not be introduced by national legislation but may only be afforded within the framework of Regulation (EC) 2081/92 (now Regulation (EC) 510/2006).

${ }^{74}$ Council Regulation (EC) No 509/2006 of 20 March 2006 on agricultural products and foodstuffs as traditional specialities guaranteed [2006] OJ L 93/1. 
Regulation $834 / 2007^{75}$ establishes conditions for the use of terms referring to the 'organic' production method (such as 'eco' and 'bio'). Such terms may be used in labelling, in advertisements or in trade marks only with regard to products which satisfy the requirements set out under, or pursuant to, that Regulation. In the case of processed food, at least 95 per cent of the ingredients (by weight) must be organic. Additional information has to be supplied as well, such as the number of the control authority.

\section{ENFORCEMENT}

\section{A Member States}

It is the responsibility of the Member States to enforce food law, and to monitor and verify that the relevant requirements of food law are fulfilled by food and feed business operators at all stages of production, processing and distribution. For that purpose, they have to maintain a system of official controls and other activities appropriate to the circumstances, including public communication on food and feed safety and risks, ${ }^{76}$ food- and feed-safety surveillance and other monitoring activities covering all stages of production, processing and distribution. ${ }^{77}$ Generally speaking, enforcement encompasses both verification of compliance with legal obligations and application of sanctions in case of infringements. Although article 17 of the General Food Law holds the Member States responsible for the enforcement of food law, European food law increasingly sets standards for national enforcement and provides for supervision. Regulation (EC) No 882/2004 of the European Parliament and of the Council of 29 April 2004 on official controls performed to ensure the verification of compliance with feed and food law, animal health and animal welfare rules includes obligations concerning: verification by the Member States; measures to be taken in case of infringement; a framework for cooperation between national authorities and the Commission; and the Commission's monitoring of the performance of national authorities in the Member States and in third countries.

Infringements of food law may cause food safety incidents. Such incidents can, however, also occur for other reasons (accidents). Incident management and enforcement can be closely related, but they are not necessarily the same thing. Incident management is discussed in the next section.

\footnotetext{
${ }^{75}$ Council Regulation (EC) No 834/2007 of 28 June 2007 on organic production and labelling of organic products and repealing Regulation (EEC) No 2092/91 [2007] OJ L 189/1.

${ }^{76}$ General Food Law, art 10.

${ }^{77}$ General Food Law, art 17(2).
} 
If a Member State establishes the non-compliance of a food business operator, it shall take action to ensure that the operator remedies the situation. When deciding which action to take, the competent authority shall take account of the nature of the non-compliance and the operator's past record with regard to non-compliance. ${ }^{78}$

Such action can include the imposition of sanitation procedures or the recall of a food product, a restriction on, or the prohibition of, the placement of foods on the market, or a closure of all or a part of the business concerned. In the case of imported products these measures may include: destruction, special treatment to solve the irregularity, and dispatch of the product back to the state of origin. For the last action a timeframe of no more than 60 days applies.

\section{B Food and Veterinary Office}

In 1997, the Food and Veterinary Office was instituted. It is not an independent agency like EFSA, but a part of DG Sanco. However, it has its headquarters in Ireland, distant from the other parts of DG Sanco in Brussels. This indicates that at least a certain degree of independence is intended.

The FVO has two main tasks. It audits the performance of national agencies and it inspects the performance of industry and public authorities in third countries that wish to export food products to the European Union. Although the FVO is not mentioned by name in the Regulation, Regulation 882/2004 provides a basis for its activities. The Member States must give all necessary assistance and provide all documentation that the Commission experts - the $\mathrm{FVO}$ - request.

These controls in third countries may only be executed if the authorities in those countries agree to them. However, as such controls may be a condition for export to the Eureopean Union, these authorities often have little alternative. The inverse situation also exists - third countries carrying out inspections in the European Union - and the Regulation requires the Commission to assist Member States in dealing with such situations. ${ }^{79}$

\footnotetext{
${ }^{78}$ Regulation (EC) No 882/2004 of the European Parliament and of the Council of 29 April 2004 on official controls performed to ensure the verification of compliance with feed and food law, animal health and animal welfare rules [2004] OJ L 165/1 ('Regulation 882/2004'), art 54.

${ }^{79}$ Regulation 882/2004, art 52.
} 


\section{INCIDENT MANAGEMENT}

EU food legislation provides instruments to deal with food safety incidents and emergencies. Information is shared among authorities, ${ }^{80}$ businesses have their responsibility ${ }^{81}$ and - in addition to the enforcement powers discussed above - public authorities are given specific instruments. ${ }^{82}$

\section{A Communication}

A system for raising a rapid alert has existed in the field of food safety since 1979. However, the scope of the former system initially did not include animal feed. The Rapid Alert System for Food and Feed (RASFF) introduced by the General Food Law, ${ }^{83}$ covers food and feed, in line with the 'farm to fork' approach.

The RASFF is a network for exchanging information about direct or indirect risks to human health deriving from food or feed. The system involves the Member States, EFSA and the Commission. Participation in the RASFF may be extended to third countries or international organisations, on the basis of agreements with the Community. ${ }^{84}$ The RASFF is the EU contact point participating in INFOSAN, the International Food Safety Authorities Network, operated by the World Health Organisation.

Where a member of the RASFF network has information about the existence of a serious direct or indirect risk relating to food or feed, it has to notify the Commission. ${ }^{85}$ The Commission is responsible for managing the network. The Commission assesses the information received and categorises the notification under one of three categories ('alert', 'information', 'border rejection') before it is passed on. The information can also be rejected from transmission through the RASFF by the Commission, if the criteria for notification are not satisfied or if the information is insufficient. The notifying country is informed of this decision.

The notification is transmitted to RASFF contact points designated by all members of the network and to EFSA. Additionally, when the notification concerns an attempt to import banned products ('border rejection'), the

\footnotetext{
${ }^{80}$ See below Part VIIIA of this article.

${ }^{81}$ See below Part VIIIB of this article.

${ }^{82}$ See below Part VIIIC of this article.

${ }^{83}$ General Food Law, art 50(1).

${ }^{84}$ General Food Law, art 50(6).

${ }^{85}$ General Food Law, art 50(2).
} 
information is sent to the EU Border Inspections Posts in order to increase their vigilance and to ensure that the rejected product does not re-enter the Community through another border post. ${ }^{86}$ And when it is known that a product subject to a notification has been exported to a third country, or when a notification concerns a product originating from a third country, the Commission also sends information to that third country. ${ }^{87}$

EFSA's role is to analyse the content of the notification and to supply scientific and technical information that will be helpful to Member States.

\section{B Role of Businesses}

The primary responsibility for ensuring that foods or feeds satisfy the requirements of food law rests with the food business operators. ${ }^{89}$ If the operators have reason to believe that their food or feed is unsafe, they shall immediately inform the competent authorities and withdraw the food or feed from the market and - if need be - recall it from the consumers. During these procedures, the operators are obliged to collaborate closely with the enforcement authorities. ${ }^{90}$

\section{Role of Authorities}

\section{$1 \quad$ National Authorities}

National authorities in the Member States enforce food law, and monitor and verify whether food and feed business operators comply with the requirements of food law. In some cases, problems will be notified to the national authorities by food or feed business operators, who will also initiate withdrawals and recalls. There will be other instances where a problem is identified by the authorities, whether through inspection, outbreaks of disease, the testing of food samples or complaints by either consumers or competitors. A food alert may also result from information received through the RASFF. The authorities are the contact point for information and communication about the food or feed incident, and they coordinate investigations relating to withdrawals and recalls on a larger scale.

\footnotetext{
${ }^{86}$ General Food Law, art 50(5).

${ }^{87}$ General Food Law, art 50(4).

${ }^{88}$ General Food Law, art 50(2).

${ }^{89}$ General Food Law, art 17(1).

${ }^{90}$ General Food Law, art 19.
} 
When the national authority adopts measures aimed at restricting the placing of the food on the market or at forcing the withdrawal or recall of food or feed, it shall immediately notify the Commission under the RASFF. It shall also inform the Commission of rejections of consignments at its Border Inspection Post, and of recommendations or agreements with food/feed business operators preventing, limiting or imposing special conditions on the placing on the market, or the use, of food or feed on account of a serious risk to human health requiring rapid action.

\section{European Commission}

Before the General Food Law entered into force, the mechanisms by which the Commission adopted emergency measures were different under various areas of legislation. Now, the scope of the emergency measure introduced in article 53 of the GFL covers all types of food and feed, whether originating in one of the Member States or in a third country. This uniformity helps to ensure consistency and adequate management of the risks applying to different categories of foods or feeds. Where a food or feed is likely to constitute a serious risk to human health, animal health or the environment, and where - given the gravity of the situation - the risk cannot be contained satisfactorily by means of measures taken by the Member State(s) ${ }^{91}$ concerned, the Commission shall:

- $\quad$ suspend the placing on the market of the food/feed in question;

- lay down special conditions for the food/feed in question;

- adopt any other appropriate interim measure.

The Commission can initiate such action at the request of a Member State, but also on its own initiative. If the Commission, following information from a Member State on the need to take emergency measures, does not initiate the procedure for the adoption of emergency measures at Community level, article 54 of the GFL empowers the Member State in question to adopt interim protective measures. The Member State may maintain its national interim protective measures until a Community decision has been adopted concerning the extension, amendment or abrogation of the said measures.

${ }^{91}$ The so-called subsidiarity principle applies. If action by the Member State(s) can solve the problem, the Commission should not become involved. 


\section{LIABILITY AND CONSUMERS RIGHTS}

Even though the first and foremost objectives of EU food law are to protect consumers' health and other consumers' interests, no provision can be found which actually grants the individual consumer a right that $\mathrm{s} / \mathrm{he}$ can uphold in a court of law.

Nevertheless, EU food law increasingly mentions 'consumers' rights' ${ }^{92}$ If we take a closer look at the way food law protects these rights, they turn out to be about empowerment in the marketplace, not in the courts of law. Actual legal rights for consumers have to be found outside the scope of food law.

For example, while food law does not directly provide consumers with legal rights, it does influence the rights they have based on other areas of law. By defining the legal requirements for food, it gives substance to the contracts consumers conclude with food businesses. In general it is fair to interpret consumer contracts as being about food which is in compliance with the law. If the food is not in compliance, it should not be too difficult for the consumer to get a refund. Infringements of food safety requirements may also easily constitute a basis for non-contractual (tort) liability.

Consumer law has created an instrument meant to support the consumer in tort litigation against producers of defective products, called product liability law. The rules on product liability have been harmonised in the European Union by Directive $85 / 374 .{ }^{93}$ Directive $85 / 374$ lays down the principle of strict liability of the producer, which means that a producer may be held responsible for damage caused by a defective product which $\mathrm{s} / \mathrm{he}$ has put on the market even in the absence of fault.

\section{Science-Based Food LaW}

The European legislature has pronounced a principle that EU food law is based on risk analysis. ${ }^{94}$ At first sight the statement that EU food law is to be

\footnotetext{
${ }^{92}$ See for the latest example (at the time of writing) the proposal for a consumer food information regulation (COM(2008) 40 final).

${ }^{93}$ As amended by Directive 1999/34/EC of the European Parliament and of the Council of 10 May 1999 amending Council Directive 85/374/EEC on the approximation of the laws, regulations and administrative provisions of the Member States concerning liability for defective products [1999] OJ L 141/20.

${ }^{94}$ See also B M J van der Meulen, 'Science based Food Law' (2009) 1 European Food and Feed Law Review 58.
} 
based on risk analysis raises high expectations. These do, however, meet with some disappointment. An innocent bystander might have expected that, as of the entry into force of the General Food Law, DG Sanco would ask EFSA's opinion on each proposal for new food safety legislation (such as the big packages on GM and hygiene). If article 6 GFL is to be understood to require the legislature to ask for scientific advice in preparing food safety legislation, it may well be the single most infringed provision of EU food law. Never does DG Sanco ask EFSA for an opinion on general provisions in food legislation.

If we take a closer look at the opinions available on EFSA's website, ${ }^{95}$ they virtually all refer to specific substances or food products or to claims made with regard to such substances or food products. Technically speaking, decisions regarding such substances, products and claims are laid down in the form of legislation. ${ }^{96}$ In substance, however, they are case specific decisions rather than general norms.

Reconciling the interpretation of article 6 of the GFL with the practices of DG Sanco and EFSA, we can see that in essence the 'general principle' of food law is the rule that decision-making on the marketability of specific substances or products must be based on scientific advice. Considered against the background of the European Union's obligations in the global arena this makes sense. Members of the WTO are obliged to avoid unnecessary barriers to trade. Ultimately, trade barriers will always have their effect on specific products. Ultimately, the question whether a trade barrier is necessary to protect human health, under WTO-law is a question of science. ${ }^{97}$

In EU food safety law, two different types of question are asked of science, depending on the type of decision at issue. Decisions may entail restrictive measures (for example measures limiting the market access of products) or measures lifting restrictions (for example granting market access to products). In the first situation, scientific substantiation justifying the measure to be taken answers the question of whether the product is unsafe. In the second situation the question is whether the product is safe. Or, to put it differently, in the first situation science is asked to identify hazards and risks; in the second

\footnotetext{
${ }^{95}$ See European Food Safety Authority < www.efsa.europa.eu > at 16 August 2009.

${ }^{96}$ See also on this C Povel and B M J van der Meulen, 'Scientific Substantiation of Health Claims: the Soft Core of the Claims Regulations' (2007) 2 European Food and Feed Law Review 82.

${ }^{97}$ See for example the WTO Agreement on the Application of Sanitary and Phytosanitary Measures, art $5<\mathrm{http}: / /$ www.wto.org/english/tratop_e/sps_e/spsagr_e.htm $>$ at 2 November 2009.
} 
situation it is asked to exclude the possibility of hazards and risks. Obviously, differences in questions asked lead to differences in burden of proof, standard of proof and consequences if risk assessment fails to come up with satisfactory answers.

Where science is asked to identify hazards, the burden of proof is usually on authorities. In procedures where science is asked to exclude hazards, the burden of proof - or at least the burden of providing scientific data - is on businesses that want to bring a product to the market. ${ }^{98}$

\section{CONCLUSIONS}

In this contribution I have attempted to present an overview of food law in the European Union in civil law style. That is to say, I have been looking for the system behind the law and have taken this system as a framework for presenting the subject matter. However, system alone will not be sufficient to provide understanding. For this reason I have devoted ample attention to history as well. In its history, EU food law has developed from being singlemindedly market-oriented to including consumer protection.

To label 'food law' as a 'functional' area of law indicates that a choice has been made to base scholarly attention on societal phenomena rather than on doctrinal distinctions. This is in itself nothing new. In environmental law, for example, the same has been done.

Several considerations argue in favour of giving special attention to the regulatory embedding of the food sector. The sector is large worldwide and of primal importance to all people. Furthermore it is fun. Everything relevant in law is happening in the food sector. Here we see different approaches to regulation - economic regulation and science-based risk regulation; we see public policy based on political decisions and we see the use of independent authorities based on technical expertise. Food law is developing at all levels of law. It is a global, regional and national phenomenon. The participation of the WTO and the development of the Codex Alimentarius attest to its universality. Finally, it can be done. I hope that this contribution shows that it is possible to approach food law as a well-structured package.

\footnotetext{
98 This distinction runs parallel to the distinction between the abuse principle and the prohibition principle discussed in Part IV of this article.
} 
I congratulate Deakin University on choosing - as the first university in Australia - to join the emerging international community of food law and on showing the initiative to take leadership in a new international association. ${ }^{99}$

\footnotetext{
${ }^{99}$ Materials that may help the reader to gain further access to EU food law are: EU legislation and case law available at $<$ http://eur-lex.europa.eu/nl/index.htm $>$; Information on EU food law available at $<$ http://ec.europa.eu/food/ >; Bernd van der Meulen and Menno van der Velde, European Food Law Handbook, Wageningen Academic Publishers, 2008 $<$ http://www.wageningenacademic.com/foodlaw $>$; the European Food and Feed Law Review < http://www.lexxion.eu/effl/ >; and the website of the European Institute for Food Law $<$ www.food-law.nl $>$.
} 